\title{
Influence of $\gamma$ Irradiation on Concrete Strength
}

\author{
V. Sopko, K. Trtík, F. Vodák
}

Aging of concrete due to gamma irradiation. Strength of concrete are in a good correspondency with already known results.

Keywords: concrete, gamma irradiation, strength.

\section{Introduction}

Mechanical properties of concrete are changing in the course of its ageing. Ageing of concrete is accelerated by climatic conditions, mechanical stress, aggressive liquid, etc. This article deals with a question of irradiation influence, which arises, for example, as a consequence of uranium ${ }^{238} \mathrm{U}$ and ${ }^{235} \mathrm{U}$ fission reaction in the nuclear reactor. It concerns neutrons and gamma irradiation acting on concrete constructions and accelerating their surface and internal changes. The concrete in these facilities plays not only the structural role, but also the role of shielding material that has to absorb the aforementioned types of irradiation and prevents their penetration. Of the irradiation spectrum we will observe only influence of gamma irradiation. The gamma irradiation is being absorbed at the passage through concrete, what can induce water radiolysis [1] in the material and consequently chemical reactions leading to changes of the concrete phase composition [2] and thus the hydration degree decrease. We can expect that this hydration degree decrease becomes evident by the decrease of the concrete strength. This hypothesis is being proved in this article.

\section{Concrete composition}

Samples determined for testing were made according to the formulation, which is stated in Table 1 [3]. This formulation was used at construction of the containment of the nuclear power plant Temelín. Composition of cement CEM I 42,5 R Mokrá is listed in [3]. Concrete beams, on which consequently the experiment took place, were made of this mixture. Volume mass of concrete 28 days old was $2358 \mathrm{~kg} \times \mathrm{m}^{-3}$.

Table 1: Composition of $1 \mathrm{~m}^{3}$ of concrete

\begin{tabular}{|l|c|}
\hline Component & Mass \\
\hline Cement & $499 \mathrm{~kg}[42,5 \mathrm{R}]$ \\
\hline Water & $215 \mathrm{~kg}$ \\
\hline $\begin{array}{l}\text { Plasticizer } \\
\text { (Ligoplast SF) }\end{array}$ & $2.8 \mathrm{~kg}$ \\
\hline Aggregates: & \multicolumn{2}{|l}{} \\
\hline $0-4 \mathrm{~mm}$ & $705 \mathrm{~kg}$ \\
\hline $8-16 \mathrm{~mm}$ & $450 \mathrm{~kg}$ \\
\hline $16-32 \mathrm{~mm}$ & $527 \mathrm{~kg}$ \\
\hline
\end{tabular}

\section{Method of irradiation}

Irradiation was carried out in the company Bioster a.s. Veverská Bítýška, where ${ }^{60} \mathrm{Co}$ is used as a gamma irradiation source. The activity of source ${ }^{60} \mathrm{Co}$ at the beginning of experiment was $A=462 \mathrm{kCi}\left(1.73 \times 10^{16} \mathrm{~Bq}\right)$ and at the end of experiment was $449 \mathrm{kCi}\left(1.68 \times 10^{16} \mathrm{~Bq}\right)$. These values were necessary for calculating of total radiation dose rate which was $0.935 \mathrm{kGy} \times \mathrm{h}^{-1}$. Concrete beams at dimensions $0.4 \times 0.1 \times 0.1 \mathrm{~m}$ after 90 days from concreting were used for the experiment. Each beam had gamma irradiation dosimeters fixed on it. Beams were irradiated for 90 days with a dosing input of approx. $0.25 \mathrm{kGy} \times \mathrm{h}^{-1}$, i.e. the maximum dose was $0.5 \mathrm{MGy}$ for the whole period of irradiation. The difference between radiation dose rates is caused due to items,

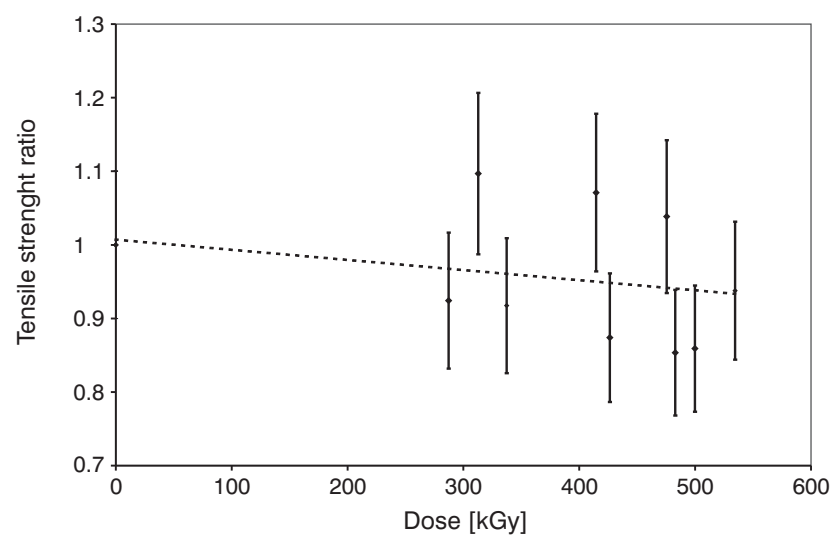

Fig. 1: Dependence of tensile strength ratio on dose

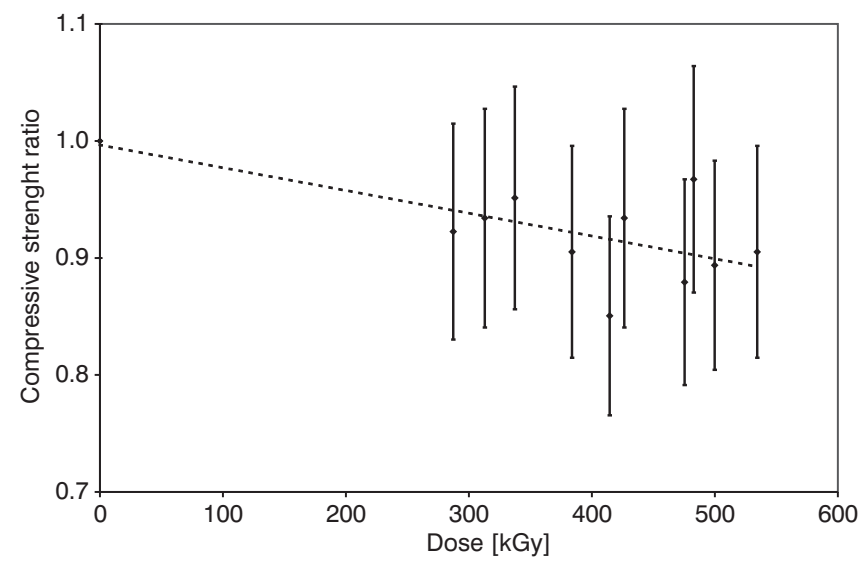

Fig. 2: Dependence of compressive tensile strength ratio on dose 
which were placed between source of radiation and irradiated samples. Classical rectifying diodes calibrated by means of standard dosimeters were used as dosimeters [4], which error is about twenty per cent. Standard dosimeters are limited for higher doses of the gamma irradiation, therefore, the dosimeters, which we used, were calibrated for lower doses and consequently extrapolated for high irradiation doses.

\section{Method of strength measurement}

At first, the flexural strength test (three - point supporting) was applied to concrete samples. After this destructive test the compressive strength test was used on the first fragment (in accordance with ČSN 7313 18) and the tensile strength test on the second fragment of splitting (in accordance with ČSN 7313 17).

\section{Conclusion}

Measured values of concrete strength (Fig. 1, 2) are according to current measurments obtained by various experimentators viz [5].

\section{Acknowledgments}

This work was supported by MŠMT ČR (Contract No. J 04-098-2100000 20).

\section{References}

[1] Assessment and management of ageing of major nuclear power plant components important to safety: Concrete containment buildings (Pachner J.); IAEA - TECDOC 1025, IAEA- Vienna 1998, ISSN1001-4289.

[2] Bouniol P., Aspart A.: "Disappearance of oxygen in concrete under irradiation: the role of peroxides in radiolysis." Concrete and Cement Research, Vol. 28 (1998), No. 11, p. 1669-1681.

[3] Vodák F. et al: Trvanlivost a stárnutí betonoryých konstrukcí jaderných elektráren. FSV ČVUT, 2002.

[4] Prouza Z., Obraz O., Sopko B., Spurný F., Škubal A.,Kits J., Látal F.: "Dosimetric Parameters of a New Czechoslovak Neutron Si Diod." Radiation Protection Dosimetry, Vol. 28 (1989), No. 4, p. 277-281.

[5] Kaplan M. F.: Concrete Radiation Shielding (Nuclear Physics, Concrete Properties, Design and Construction), Longman Scientific \& Technical, England, 1989.

Ing. Vít Sopko

phone: +420224354435

e-mail: sopko@fsv.cvut.cz

Department of Physics

Doc. Ing. Karel Trtík, CSc. phone: +420224354626

e-mail: trtik@fsv.cvut.cz

Department of Concrete Structures and Bridges

Prof. František Vodák, DrSc.

phone:+420224353886

e-mail:vodak@fsv.cvut.cz

Department of Physics

Czech Technical University in Prague

Faculty of Civil Engineering

Thákurova 7

166 29, Praha 6, Czech Republic 